\title{
Exploring Perceptions of Religion and Science among Turkish Academics
}

Kenan Sevinç

Canakkale Onsekiz Mart University

İlahiyat Fakültesi, Şehitler Yerleşkesi

Canakkale, 17020, Turkey

e-mail: kssevinc@gmail.com

Thomas J. Coleman III

Coventry University

Centre for Trust, Peace and Social Relations

Cheetah Road, IV5 Innovation Village

CV1 2TL Coventry, UK

e-mail: colema56@uni.coventry.ac.uk

Miguel Farias

Coventry University

Centre for Trust, Peace and Social Relations

Cheetah Road, IV5 Innovation Village

CV1 2TL Coventry, UK

e-mail: ab7893@ coventry.ac.uk

Abstract:

The religiosity of academics has been studied for over a decade. With few exceptions, this research has been conducted on American "elite" scientists, and data from non-Western countries is lacking. Drawing from psychological and sociological literature, the present exploratory study investigates the religiosity of Turkish academics $(\mathrm{N}=361)$ and their perceptions on the relationship between religion and science, and associated variables such as interpretation of the Quran, and belief in evolution and creationism. Moreover, we address criticism directed at previous research by probing for different God concepts among believing academics. Although cultural differences can be identified, the results generally support the idea that academics are less religious with 54\% identifying as "less religious" or "not religious," compared to $24.2 \%$ self-identifying as "religious" or "extremely religious."

Keywords: religion, religiosity, academic, science, Turkey, belief. 


\section{Introduction}

At a time when the topic of atheism was still at the fringes of society, psychologist James Leuba's discovery [57] that the majority of the elite American scientists he surveyed in 1914 and 1916 did not believe in God was shocking [53]. From today's perspective, it may be puzzling that proponents of the secularization thesis (e.g., [32], [57], [91]) thought advancements in scientific knowledge would play a central role in the erosion of religious beliefs in society. Certain aspects of religiosity have declined since the turn of the last century [14], but religious beliefs are still held by the majority of the world's population [45]. Science has not proved to be the antidote to religious thinking as once thought. For elite scientists and other academics however, the picture is typically quite different, and Leuba's groundbreaking research [57] into the religiosity of scientists has seen renewed interest in recent years. Building on the work of Leuba and others (e.g. [4], [29]) we replicate the findings of previous research conducted primarily in the American context and introduce new empirical data on the religiosity ${ }^{1}$ of, and perceived conflict between, scientificevolutionary, and religious thinking of academics (full professors) in Turkey - an under studied country with an important context due to its relationship with secularism [80]. Before introducing the Turkish cultural context of the present research, we proceed by reviewing scholarship on the religiosity of elite scientists and academics in general, differences in religiosity by academic discipline, differences between academics and the public, and factors contributing to these relationships.

\section{The Religiosity of Elite Scientists}

Rather than inquiries into the religiosity of academics in general, most research has focused only on "elite" or top scientists. This has occurred for two reasons. 1) If elite scientists, holding the best knowledge and thinking skills in society did not believe in God, Leuba reasoned, this was further evidence of the incompatibility of religious beliefs with scientific thinking [57]. While it is generally accepted that the cognitive processes required for scientific thinking contrasts with those required for everyday religiosity [61], [60], this does not suggest any incompatibility in their overall framework per se [42]. 2) A more precise justification for focusing on elite scientists has been developed by Ecklund and Park [27]. They argue that elite scientists are more likely to impact the creation and maintenance of knowledge, which contributes to a broader understanding of the dynamics of academia as an institution. While there remain scientists, indeed even elite scientists, who identify as religious and practice their faith (cf. [29]), the primary focus of our introduction is on the overwhelming nonreligiosity of scientists.

That eminent scientists are less religious is supported by a range of studies, the first of which conducted in the early $20^{\text {th }}$ century. Across 3 separate studies of elite American scientists (culled from the 1910 edition of American Men of Science) conducted in 1914, 1916, and 1933 [56], [57]. Leuba explored two key aspects of religiosity: belief in immortality and belief in a personal God. In each sample, the majority of the respondents were either atheists or agnostics (58-85\%) with a similar pattern for disbelief or doubt in immortality (69\% in 1914 and 82\% in 1933) except for his 1916 sample (50\%) [56], [57]. Leuba's methodology has been criticized by Stark for over inflating nonbelief and doubt due to the wording of his questions focusing on a highly personal concept of God (cf. [85]) - thereby excluding deist, pantheist, and panentheistic notions of God, for example. While we are sympathetic to Stark's critique, that elite scientists are less religious is supported by a variety of evidence in addition to Leuba's original studies.

For example, Roe conducted interviews with 64 top scientists and found the majority were uninterested in religion, and "a few were militantly atheistic" [9, p 110], [74]. In a study of 87 top research scientists conducted by Bello, 40 were either atheist or agnostic and a further 19 reported no religious affiliation [10]. These smaller qualitative studies notwithstanding, quantitative research conducted in the 1950's and 60's has sought to mimic aspects of Leuba's approach [57]. For example, although Vaughan, Smith, and Sjoberg's research did not explore belief in God, among 
elite scientists (again sampled from American Men of Science), rates of reported denominational membership were $76 \%$, however $38.5 \%$ also claimed no religious attendance with an additional $16.8 \%$ reporting only once per month [89, p. 524]. Interestingly, $63.9 \%$ of their respondents either rejected belief in life after death or were undecided [89, p. 521]. Thus, the discrepancy between reported membership, religious attendance, and even higher rates of agnosticism towards or an outright denial of belief in immortality suggests a "believing in belonging" effect (cf. [21], [22]) could have contributed to the unusually high rates of membership.

The most recent attempts to directly replicate Leuba's original approach [57] are more conclusive (and instructively, parallel Vaughan et al. immortality findings [89]). For example, Larson and Witham randomly selected 1,000 scientists (roughly 600 responded) from the 1995 issue of American Men and Women of Science, finding 60\% were atheist or agnostic and 62\% either disbelieved or doubted the possibility of human immortality [53]. In an additional study published the following year, they sampled the 517 members of the National Academy of Sciences (roughly 260 responded), finding an overwhelming majority were atheist or agnostic with only $7 \%$ professing belief in God and 8\% believing in immortality [52]. In an alternative, broader, approach to studying elite scientists, Ecklund and Park sampled from 21 top research universities in the United States (US) [27]. Although belief in immortality was not examined, they found $63.7 \%$ of their sample reported being atheist or agnostic, while only $8.8 \%$ reported having no doubt's about God's existence. Philosophers have not typically been considered "scientists" in many of these studies, and therefore excluded, however among the top 99 philosophy departments in the world, almost $73 \%$ of Bourget and Chalmer's $(N=1,972)$ sample self-identified as atheist [11].

\section{The Religiosity of Academics}

The evidence in favor of the nonreligiosity of elite scientists is informative, however they are a minority population when compared to the greater number of professional academics in general [64], The Academy's Dirty Secret 2015). Therefore, the broader college professorship has more opportunities to influence a greater number of students. Indeed, research suggests that peer influences during college contribute to changes in religiosity [8]. Rather than science and elite scientists serving as unique secularizing forces, academia as an institution may contribute to a decline in religiosity. For example, among U.S. adults, $14 \%$ of college graduates compared to $6 \%$ with a high school education or less identify as a nonbeliever [69]. Moreover, research has identified an inverse correlation between levels of education with religiosity (e.g. [41], [65], [75], [92], [78]), but others have not identified any relationship (e.g. [18], [39], [82]). Far less research has examined the religiosity of university faculty at community colleges and institutions that only grant undergraduate degrees. For example, in their sample of 37,827 faculty members at 2 and 4year colleges, Lindholm and Astin found that $82 \%$ of their respondents had medium to high scores on a measure of spirituality [58]. However, their measure of spirituality contained no references to God or the supernatural, and some nonbelievers do self-identify with nontheistic spirituality (e.g. [15], [70]). In a representative sample of fulltime professors, Gross and Simmons reported that 75\% believed in God or a higher power and 23\% were atheist or agnostic [36]. When compared to the numerous studies on elite scientists or college students, research into the religiosity of professional academics is an understudied area requiring further investigation.

\section{Differences in Religiosity by Discipline}

In addition to examining differences in religiosity among elite scientists and professional academics, research has investigated field-specific differences between, and within the natural and social sciences. In his seminal study, for example, Leuba found higher rates of atheism and agnosticism among elite biologists (69.5\%) compared with elite physicists (56.1\%) [57]. Unfortunately, his research did not survey social scientific disciplines (i.e. the "softer sciences," such as psychology) for comparison as contemporary studies have done. Using data from over 
60,000 American college professors collected in 1969, for example, Stark, Iannaccone, and Finke found academics in disciplines like psychology (33\%) and anthropology (29\%) were less likely to be religious than those in mathematics (60\%) or the physical and life sciences (55\%) [84]. Additional studies comparing only psychologists to other academics also support this pattern [36], [55], [73].

Gross and Simmons found academics in disciplines such as accounting, finance, marketing, art, nursing, and economics, for example, were more than twice as likely to report they "know God really exists" and "have no doubts about it" than those in psychology, mechanical engineering, political science, biology, or English. Moreover, 52\% of physical and biological scientists were atheist or agnostic compared to $29 \%$ of humanities scholars [36]. Nevertheless, other research has found less dissimilarity between these disciplines than identified by Gross and Simmons. For instance, Ecklund and Scheitle found less disparity between the percentage of atheists/agnostics, as well as the absence of religious service attendance, in the natural sciences, $(67 \% ; 55.3 \%)$ compared to the social scientists $(62.2 \% ; 50.3 \%)$ [26] (also see [77]). Similar results have also been identified by Lindholm and Astin's study, finding academics in the social sciences (68.5\%) are not too dissimilar compared to those in the biological (71.6\%) and physical sciences $(71.9 \%)$ in their lack of "spirituality" [58]. Moreover, rates of religious practice between social and natural scientists, suggest similar patterns. In both groups, roughly half report never attending, and additional 1/4 to $1 / 3$ report attending religious services only several times a year [27], [26]. In summary, fieldspecific differences toward nonreligiosity - if not outright nonbelief - are evident among professional academics and tend to be most pronounced in the natural sciences (vs. humanities/social sciences), with psychologists and biologists being the most consistently nonreligious.

\section{Documenting More Differences: Academics vs. the Public}

Having discussed disparities in the religiosity between different types of academics, and differences across disciplines, we turn to research comparing academics with the general U.S. population. Here too, a trend towards nonreligiosity in general and nonbelief in specific not only persists but increases substantially. For example, using data from the 1998 General Social Survey, Ecklund finds $51.8 \%$ of scientists identify as a "religious none" compared to $14.2 \%$ of the general population [29]. Moreover, even when academics do identify with a specific denomination, they typically report this as a "liberal" or "progressive" variant (e.g. [29], [27], [36], [89]. Moreover, scientists $(1.5 \%)$ are more than 9 times less likely to be evangelical/fundamentalists than their rates among the general public (13.6\%; [29]). According to the Pew Research Center Public Opinion on Religion and Science in the United States poll, scientists drawn from the prestigious American Association for the Advancement of Science (41\%) are almost ten-times more likely to be nonbelievers than the general population (4\%) [66]. When comparing rates of religious attendance between scientists and the general population, they are more than twice as likely to never attend, and only $18 \%$ attend one or more times a month compared to $46 \%$ of the public [29, p. 37]. Although the above differences are most pronounced for elite scientists (the focus of most of the extent research), professional academics as a whole, and individuals with advanced degrees are less religious than the general population [36], [41], [65], [84]. This begs the question: What are the possible sources of these differences?

\section{The Familiar Background of Nonreligion and Conflict: Family and Evolution}

What are the possible sources of perceived science-religion conflict and the development of nonreligiosity? Ecklund and Scheitle find that "most of the family characteristics generate the same effect among academics as they do among the general population" [26, p. 301]. In other words, for example, factors such as the importance of religion in one's family and the family's religious background (e.g. Jewish; cf., [9]) exert similar influences on the religiosity of academics [26], as 
well as nonreligiosity in general [51]. In sum, variables like family income, marital status, number of children, age, race, political orientation, and geographic location, have all been found to impact the religiosity of academics and the general public [36], [58], [66], [89], (see also [46]). But setting aside predictors of religiosity, what are the primary influences for perceived religion-science conflict?

One of the most familiar points of conflict stem from diverging understandings / teachings of the implications of Darwin's theory of evolution by natural selection for religious truth claims [4], [6], [20]. Indeed, philosopher Daniel Dennett's metaphor for Darwinian thinking is a sort of universal acid that dissolves many of humanity's most cherished assumptions - religious or not [23]. Although some academics claim the conflict is not over evolution per se, but its foundation in materialism (which is often mistaken for atheism e.g. [4], [42], cf. [17]), these more abstract and convoluted dialogues - as important as they may be - remain the troupes of highly trained philosophers, theologians, and scientists.

The average person on the street is unlikely to provide a sound justification for their particular view irrespective of their religiosity. As psychologists are well aware, intuitions appear first, followed next by rationalizations [34] (but do not mistake this for irrationality per se: [61]). This is one reason, for example, research suggests scientific (natural) and religious (supernatural) explanations co-exist across cultures and human development [54]. Nevertheless, there are many approaches to the possible relationships between religion and science discussed ad nauseam elsewhere (cf. [7], [35], [83]). Research suggests that both academics and the public generally perceive the relationship between science and religion akin to Gould's notion of non-overlapping magestria [35]; more or less separate domains that do not have to conflict [4], [28], [27], [89]. Nevertheless, it is also recognized that to the extent some religious claims overlap with empirical claims (e.g., age of the earth for young earth creationists), there can be undeniable conflict (also see, [66]). In fact, in addition to strong nonbelievers in God, perceived conflict is most robust among religious fundamentalists (i.e. biblical literalists; [4], [27]). When Ecklund and Park examined perceived religion-science conflict in elite scientists, the importance of religion at age 16 was a stronger predicator than variables such as maintaining one's religious affiliation, religious switching, or disaffiliating ${ }^{2}$ [27].

There is an undeniable, but often exaggerated, link between scientific-evolutionary thinking and nonreligiosity, especially for scientists [5], [71]. But this does not entail evolutionary thinking will erode religious belief, and the research discussed thus far indicates factors unrelated to scientific-evolutionary education contribute to the development of nonbelief. Rather ironically, one of the greatest triumphs of scientific-evolutionary thinking has been to explain and understand the ubiquity, success, and persistence of religious beliefs throughout history and into the present [12], [61], [60]. Nothing entails a good believer cannot be a good academic and evolutionist (e.g. [38]). However, the prestige of academia (cf. [9]), particularly Darwinian Evolution, has been appropriated equally by atheists and theists to support their respective worldviews (cf. [16]). Pragmatically, the main tragedy ${ }^{3}$ of the perception that science and religion are in conflict comes in the form of the active rejection of scientific-evolutionary thinking. While the most familiar examples have occurred in the U.S. context (e.g., the "Scopes Monkey Trial" in 1925 and more recently, [48]) - also where the majority of research has been focused (for an exception, see [28]) one of the most recent clashes in the religion-science conflict comes from the country of Turkey.

\section{The Turkish Cultural Context of Religion and Science Research}

In 2017 Darwin's theory of evolution was removed from statewide school curriculums in Turkey [62]. This is a text-book example of the various discourse and perplexities surrounding the perceived religion-science conflict and its relationship to academics. The current research is therefore well timed for having occurred shortly after this change in governmental policy - a cogent example of perceived conflict and its possible consequences. Given Turkey's unique regional history as the only democratic country with a Muslim majority population, and a constitutionally 
secular government (cf. [80]), this makes researching the perceptions of religion, science, and conflict among Turkish academics all the more important. Moreover, we know of only a single study that has examined these perceptions among Turkish academics (scientists in this case, see [28]), and past research has been overwhelmingly limited to the U.S. cultural context. Having already reviewed much of this work we turn to discuss the importance of cultural context, touching on political, linguistic, educational, and other cultural aspects of the Turkish context.

The peculiar Western context that most scientific research has occurred in can obscure important cultural differences [37] that may be relevant for the perceived relationship between science, religion, and academics. For example, a rich tradition of Islamic psychological thinking predates the Enlightenment era of Western Europe [79], and regions such as Central America have developed distinct social sciences that do not find religion and science in conflict (e.g. El Salvador; [59]). Compared to the U.S. and other contexts, in their study of several Muslim countries, Dagher and Boujaoude find science curricula is dictated by government establishments, which are closely intertwined with the dominant religious establishments [20]. For example, unlike the U.S. or El Salvador, Turkey has a long history of government control over both religious and educational institutions [80] which might influence the perceived relationship between science and religion.

For example, looking specifically at how Darwinian Evolution is presented in biology textbooks in 5 Muslim countries, Turkey was the only country without an explicit discussion of human evolution [2]. Again, this may reflect the perception that evolutionary thinking leads to atheism. Published research on atheists in Turkey is difficult to locate, however in one study by Sevinç, Turkish atheists were asked why they do not believe in God, and only $16 \%$ of those interviewed reported scientific or evolutionary reasons for their nonbelief [82]. This suggests scientificevolutionary thinking may not be a threat to religion in the Turkish context (as well as in other countries, cf. [28]), but leaves open the question of whether higher levels of education are associated with lower levels of religiosity.

Historically, many of the Turkish political elite have viewed a shrinking role for religiosity as a necessary step in the modernization of the country [47], [80], [93]. Turkey's transformation into a modern nation-state has not reduced levels of popular religiosity (98.7\%, [24], [49]). However, research suggests the more educated in Turkey are less religious in general [93], [88], show less belief-based religiosity [19], [31], and pray less often when compared to the Turkish public [44]. These findings parallel those found in Western contexts, and we generally expect similar results among Turkish academics.

Despite the inverse religion-education relationship, important cultural-linguistic differences between Turkey and other Western research contexts may be more accommodating to the maintenance of religiosity among Turkish academics. For example, the concept of atheism has its roots in the Western context of Christianity [72]. Within Muslim culture and history, there is no straightforward concept that relates to atheism and its cognates (which are belief-based) and belonging to Islam without believing it may therefore be easier to maintain psychologically (cf. [81]). Moreover, structural differences between Islam and various Christian denominations may also play an influencing role. For example, according to Brown, there is a greater focus on institutional orthodoxy and bureaucratic hierarchy in Christianity compared to Islam [13]. Thus academics, who tend to lean more liberal and less authoritarian [50], [76], [87], may find Islam more appealing and/or accommodating for its greater decentralization of authority (i.e. there is no "church" structure) [81]. Additionally, rates of deconversion are higher for individuals with a Christian vs. a Muslim background (ibid). Compared to the U.S., where the "spiritual but not religious" category has been growing substantially over the past twenty years [86], this has not occurred in Turkey, where "spirituality" is perceived to be more closely related to behavior than belief, and the term is harder to separate from religion [1], [25].

The only research conducted in the Turkish context thus far comes from Ecklund et al., who sampled scientists (biologists and physicists) from 7 other countries: France, Hong Kong, India, Italy, Taiwan, United Kingdom, and the U.S. [28]. They found $68 \%$ of the Turkish scientists sampled perceived the relationship between religion and science as either one of independence or 
collaboration (with similar rates in the other countries); $24 \%$ reported there was a conflict on the side of science and $2 \%$ reported the conflict was on the side of religion [28, p. 6]. Moreover, 33\% of the Turkish scientists sampled reported attending weekly religious services, and 54\% reported praying once a day or more (ibid). Moreover, compared to scientists from the other 5 countries sampled, Turkish scientists showed the highest rates of having "no doubts" about God's existence (61\%: 4) and the second highest rate of religious affiliation (84\%). In the present study, we extend the global research on science and religion by providing an in-depth focus on the Turkish context.

\section{Present Study}

Above, we discussed the extant research on the religiosity of academics by discipline, compared academics to the public, and discussed the contribution of demographic variables, and potential sources, and the ways in which religion and science are perceived to conflict. Moreover, we noted the majority of these studies sample only academics who are "elite" scientists in Western universities, specifically within the cultural context of Christianity. Research is needed in other cultural contexts using samples of "non-elite" academics, which comprise the majority of all professional academics [64]. To begin addressing this gap in the literature, we sampled Turkish academics and proposed the following hypotheses: The majority of Turkish academics: 1) selfidentify as less religious 2) are religiously affiliated; 3) are believers in God; 4) believers in life after death; 5) and view the Quran as "perfectly true, but it should not be taken literally, word-forword." When compared to the general population, elite academics are 6) more likely to be disaffiliated and 7) attend religious services less than the general population. And finally, we hypothesized that 8) perceived science-religion conflicts will be predicted by family religious importance at 16 years of age.

Exploratory analyses: In addition to the above hypotheses, we present several exploratory analyses looking at the diversity of God concepts, demographic associations with belief in God, afterlife, religious attendance, and religiosity; relationships between creation question and evolution question, and differences between the humanities, natural, and social sciences.

\subsection{Method}

In testing these hypotheses, we invited Turkish academics to participate in an online survey presented in English. This study was approved by the University Ethics Committee (P67535). The full survey items and original data are freely available to anyone upon request to corresponding author.

\subsection{Participants}

Out of a possible 178 universities we selected the ten largest based on the number of currently employed "full professors" (the highest academic position in Turkish universities) at each institution from the database of the Higher Education Council (www.yok.gov.tr). This strategy was the most likely to capture a broader range of typical academics in different fields, because institutes with a greater number of full professors typically have more departments than smaller institutes. Moreover, full professors have had the opportunity to influence a larger number of students than academics of other ranks in the Turkish university system.

Table 1. Ten Largest Turkish Universities Sampled

\begin{tabular}{lllll}
\hline \multicolumn{1}{c}{ Universities } & City & $\begin{array}{l}\text { Number } \\
\text { professors }\end{array}$ & of full \\
\hline Istanbul University & Istanbul & 1442 & \\
\hline Ankara University & Ankara & 1189 & \\
\hline Ege University & Izmir & 914 & \\
\hline \multicolumn{2}{c}{24}
\end{tabular}




\begin{tabular}{lll} 
Hacettepe University & Ankara & 855 \\
\hline Gazi University & Ankara & 853 \\
\hline Dokuz Eylul University & Izmir & 725 \\
\hline Marmara University & Istanbul & 674 \\
\hline Ataturk University & Erzurum & 520 \\
\hline Cukurova University & Adana & 506 \\
\hline Istanbul Technical University & Istanbul & 490 \\
\hline \multicolumn{1}{c}{ Total } & & 8168 \\
\hline
\end{tabular}

From the faculty webpages of these universities, a total of 7,394 e-mail addresses were obtained and each one emailed a link using Qualtrics online survey collection platform. After identifying duplicate or bounced emails $(n=367)$, the total survey invitations sent was 7,027 . Previous research on Turkish academics received a 39\% response rate using email and phone reminders [28]. In the current study, we anticipated the response rate would be much lower given the current political climate of Turkey, and we were unable to issue reminders by phone. Out of the 7,027 surveys delivered by email, $n=361$ were completed/returned (response rate 5.14\%). The average age of participants was 54 years $(S D=6.5), 70.1 \%$ of participants are male $(N=253$; female $=108)$, and $79.8 \%$ are married. Most of the participants (56.8\%) grew up in a large city and self-identify as adhering to Islamic religious beliefs $(68.2 \%)$.

\subsection{Measures and Analytic Strategy}

The questionnaire consisted of three parts: 1) demographic questions (e.g. gender, age, marital status), income levels are equal for professors at state universities in Turkey, with the exception of compensation paid to academics employed in the east of the country, 2) questions about their academic field, and 3) religion-science conflict questions. Based on prior research (cf. [3], [40]), participants chose from the following belief options: I don't believe in God; I don't know whether there is a God and I don't believe there is any way to find out; I don't believe in a personal God, but I do believe in a Higher Power of some kind; While I have doubts, I feel that I do believe in God; I know God really exist and I have no doubts about it; I don't know. The first two options are coded as "nonbelief" (i.e. atheism and agnosticism), and the next three are coded as belief in God or supernatural agents. Next, participants answered questions about belief in life after death, their opinions about authenticity of Quran, and the theory of evolution and creationism. Family importance of religion at age 16 was measured along with personal importance at age 16, and current religiosity levels measured on a five-point Likert-type scale anchored at 1 "not religious" and 5 "extremely religious". Scale points 2,3 , and 4 were unlabeled; we coded 2 as "less religious" and 4 as "religious". Opinions on the theory of evolution and creationism were assessed with single item measures. Participants who believed in God were then instructed to pick one of four descriptions of different God concepts which they felt best matched their God's nature, which remained un-labeled to avoid demand characteristics (theism, deism, pantheism, and for example panentheism, whose descriptor read: "Deity is the inner spiritual essence of everything in the universe. There is no a personal God. Everything composes an all-encompassing, immanent god."

\section{Results and Discussion}

Among our sample of Turkish academics, Hypothesis 1 is accepted, with the majority (54\%) selfidentifying as "less religious" or "not religious," compared to $24.2 \%$ self-identifying as "religious" or "extremely religious" $(M=2.36 ; S D=1.33)$. Hypothesis 2 is accepted: the majority (Muslim $68.1 \%$; other $2.8 \%$; Christian $.03 \%$ ) report a religious affiliation compared to being unaffiliated (i.e., not religious $28.8 \%$ ). While these hypotheses might appear contradictory, level of religiosity need not correspond directly with reported affiliation (cf. [21], for Muslim context, see [81]). 
Interestingly, religious affiliation appears lower than was identified by Ecklund and colleagues $(84 \%)$ [28].

Hypothesis 3 is accepted, the majority of academics identified with some type of belief in God $(70.4 \%$; nonbelief $=29.1 \%)$. Below, graph 1 shows the full options for belief in God. When compared to the rate of belief in God without doubts found by Ecklund et al. (61\%) [28], our sample shows much less certainty (i.e. $48.2 \%$ ). The exact reasons for this are unclear, however we reiterate our sample included only full-professor academics from all disciplines, whereas Ecklund and colleagues sample included physics and biology graduate students, post-doctoral researchers, and professors from all ranks and level of institution.

Figure 1. Belief in God among Turkish Academics.

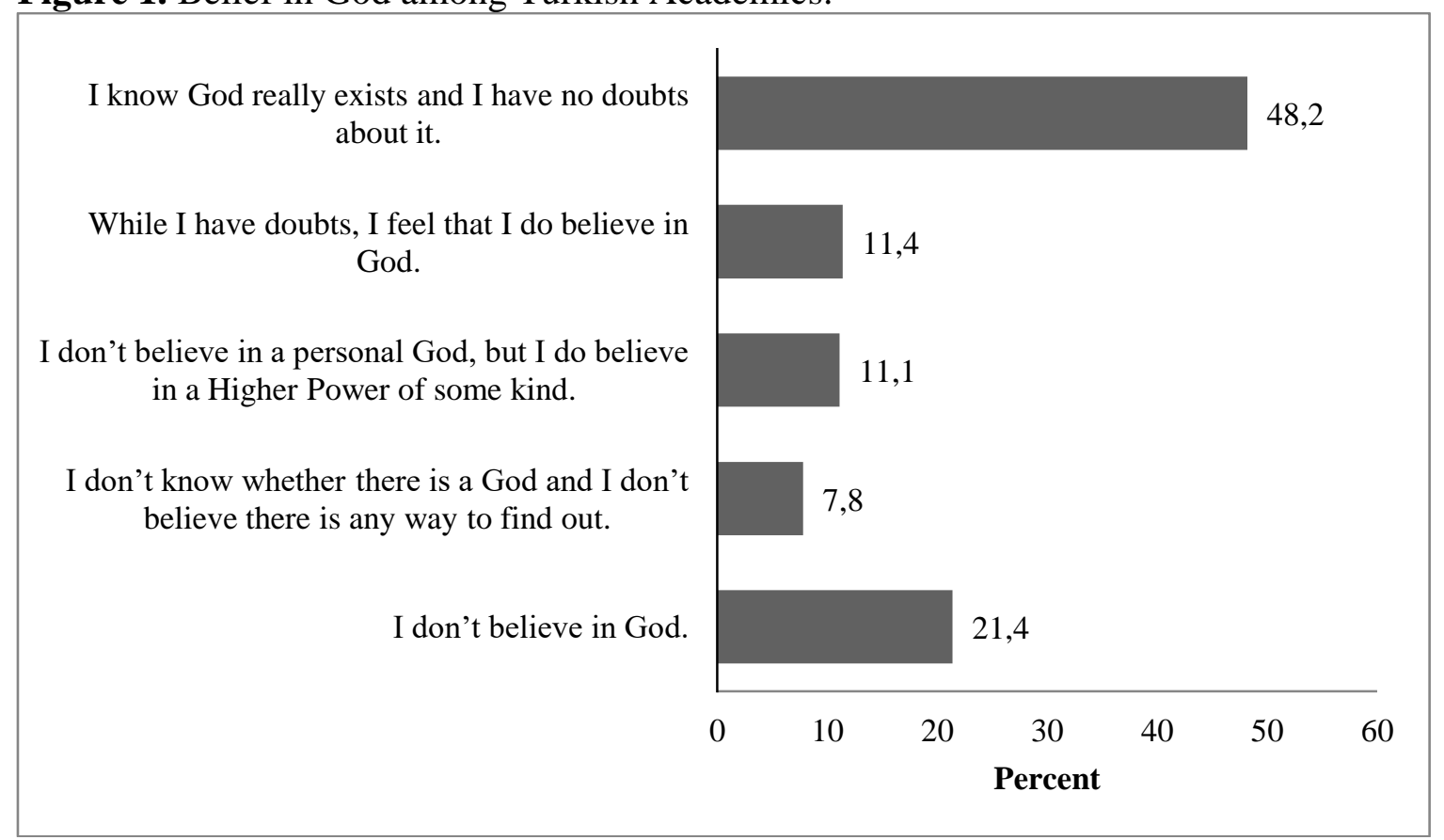

Hypothesis 4 is accepted, the majority of academics (47.1\%) believe in life after death, whereas $34.6 \%$ do not believe, and $18.3 \%$ reported they "don't know". However, we concede there is a degree of ambiguity in the meaning of "don't know" for this item. Participants may have selected it as a proxy for "no opinion" or to express agnosticism.

Hypothesis 5 is rejected. As seen in Figure 2 below, the majority of academics do not view the Quran as "perfectly true" and that "it should not be taken literally, word-for-word." Interestingly, the majority view is that it is an "ancient book of fables, legends, history, and moral precepts." However, looking at the perceived ontological status of the Quran by combining those who take a literal and non-literal view, it is evident that $52.7 \%$ of academics affirm its authenticity. Moreover, this implies that some academics believe in God, although they do not view the Quran as a book revealed by God. 
Figure 2. Views on the authenticity of the Quran

The Quran means exactly what it says. It should be taken literally, word-for-word, on all subjects.

The Quran is perfectly true, but it should not be taken literally, word-for-word.

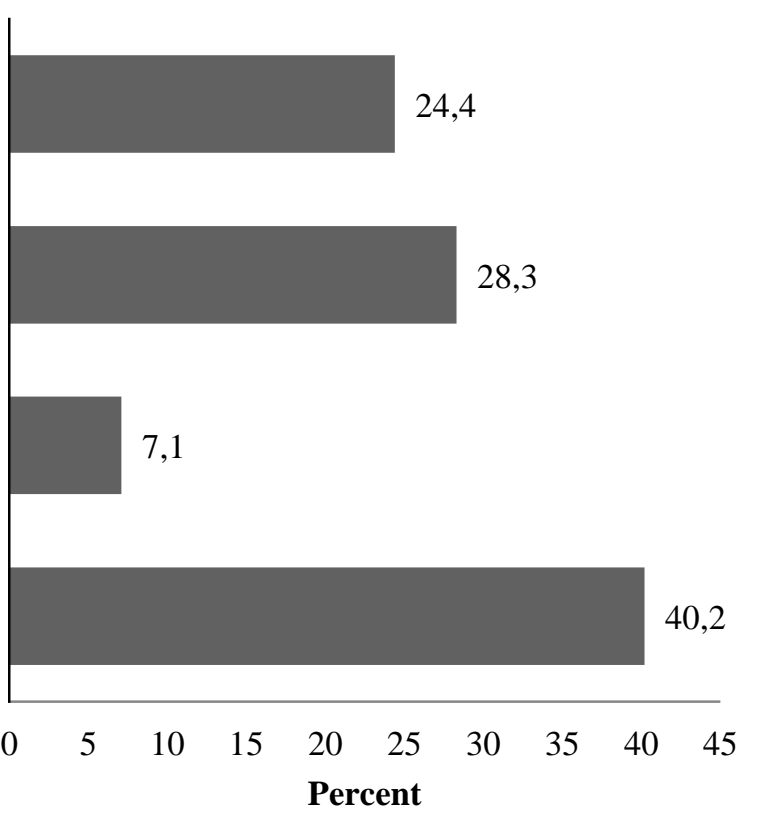

The Quran is an ancient book of fables, history, moral precepts, and legends.

Percent

Hypotheses 6 and 7 are confirmed. When compared to the general population, academics are more likely to be disaffiliated and less likely to attend religious services. Thus, similar to countries such as France, Italy, India, Unites States, and the United Kingdom there is a gap between the religiosity espoused by the public and the religiosity of the scientists [28]. In addition to this, we also include several exploratory analyses comparing academics' belief in evolution and science-religion conflict with the general population (pictured in figure 3, below), which also show a disparity similar to the U.S. context [66].

Figure 3. Belief, affiliation, evolution, and science-religion conflict view

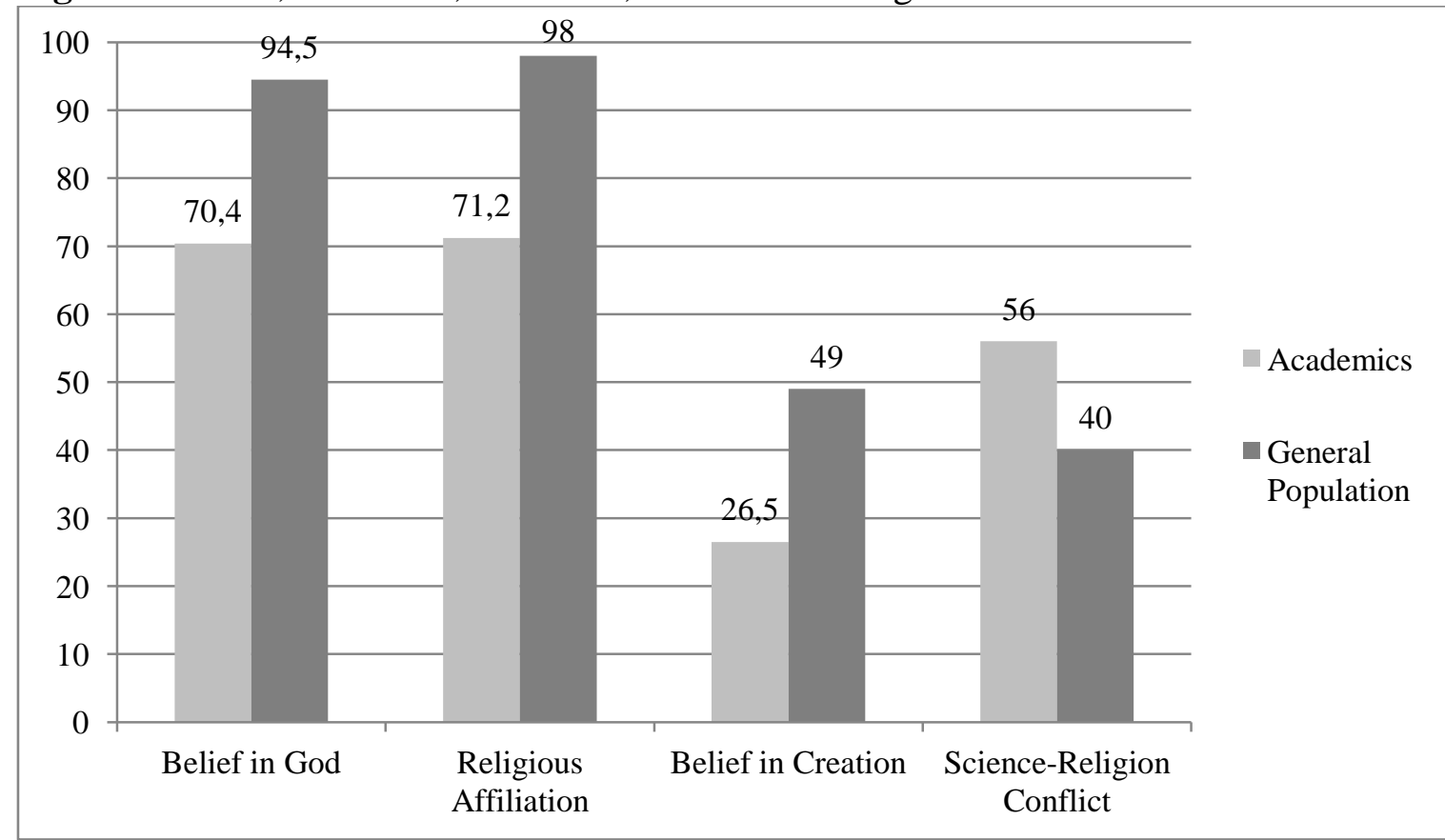

Rates for general population have been taken from European Commission [30] and Pew Research Center [67], [68].

Hypothesis 8 is accepted. Perceived science-religion conflicts are predicted by the level of family religious importance (upbringing at 16 years old), and this relationship is fully mediated by 
childhood importance of religion at age 16 and current religiosity. Family background is a predicator of perceived conflict $\left(\mathrm{R}^{2}=.11, b=-.44, \mathrm{t}=-6.3, p<.001\right)$ (also see, [27]), but only to the extent it works through one's current religiosity (Figure 4). This double mediation model is intended primarily as a "proof of concept" - it explores an intuitively obvious path to the conflict view - that one's current religiosity rather than their upbringing or importance at age 16 is the best predicator of perceived conflict.

Figure 4.

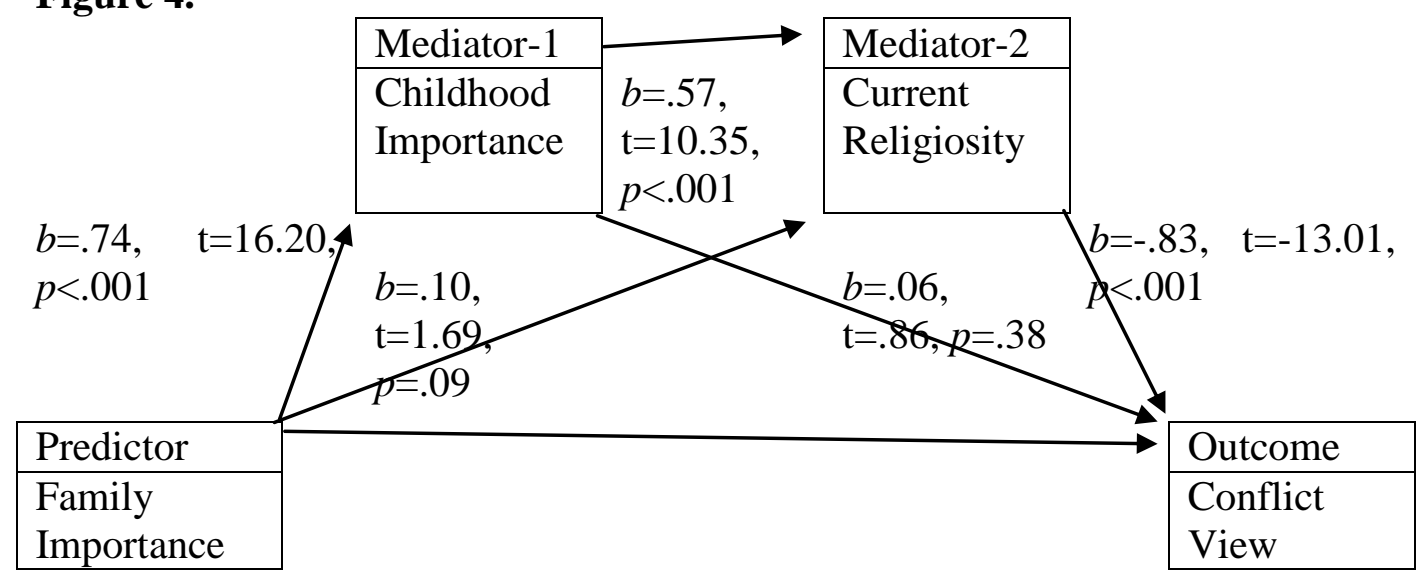

Direct effect: $b=-.04, \mathrm{t}=-.65, p=.51$

$\mathrm{R}^{2}=.45$

Total Indirect effect: $-.39,95 \mathrm{CI}[-.52$, .27]

\subsection{Exploratory Analyses}

Past research on belief in God among academics has been criticized for not examining the possibility of variation in God concepts (e.g. [85]). In Figure 5 below, we present rates of variation according to God's perceived nature. Our finding that traditional theism is a minority view when compared to all others bares similarity to previous research showing religious scientists tend to identify more with progressive or liberal denominations in the American context (e.g. [27]). In other words, holding less traditional, more abstract, God concepts in Muslim majority countries may be similar to identifying with more liberal denominations in the Christian majority countries.

Figure 5. Prevalence of different God Concepts

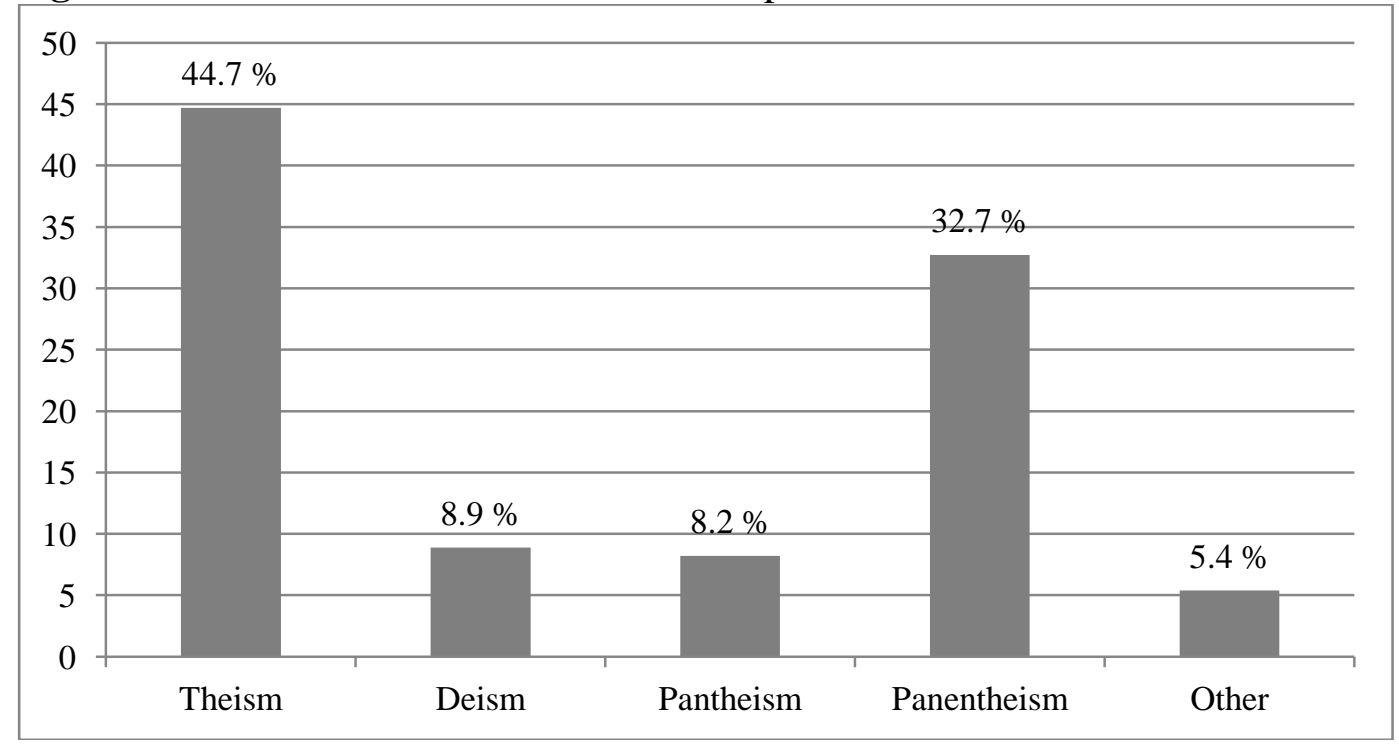


Research suggests demographic variables are also influencing factors when considering the religiosity of academics (e.g. [27]). Below, Table 2 displays differences related to demographic variables using chi-square analyses for belief in God, after life, and religious affiliation, an independent samples t-test for religiosity mean, gender, and age, and a One-way ANOVA with a Tukey HSD post hoc test, revealing differences in religiosity and marital status between married and divorced individuals $(p=.018)$.

Table 2. Association between demographics and belief in God and afterlife

\begin{tabular}{|c|c|c|c|c|c|c|}
\hline & \multicolumn{2}{|c|}{ Belief in $\mathrm{God}^{\dagger}$} & $\begin{array}{l}\text { Belief in After } \\
\text { Life }^{\dagger}\end{array}$ & $\begin{array}{l}\text { Religious } \\
\text { Affiliation }^{\dagger}\end{array}$ & \multicolumn{2}{|c|}{ Religiosity } \\
\hline & None & Believer & Yes & $\begin{array}{ll}\text { Non } & \text { Affiliat } \\
\mathrm{e} & \text { ed }\end{array}$ & $M$ & $S D$ \\
\hline \multicolumn{7}{|l|}{ Gender } \\
\hline Male & 33.9 & 66.1 & $\begin{array}{ll}37.5 & 49\end{array}$ & $28.9 \quad 71.1$ & 2.40 & $\bar{X}$ \\
\hline \multirow[t]{2}{*}{ Female } & 18.5 & 81.5 & $\begin{array}{ll}27.8 & 42.6 \\
\end{array}$ & $28.7 \quad 71.3$ & 2.26 & $\mathrm{X}$ \\
\hline & \multicolumn{2}{|c|}{$X^{2}(1)=8.593, p=.003$} & $\begin{array}{l}X^{2} \quad(2)=13.602, \\
p=.001\end{array}$ & $\begin{array}{l}X^{2}(1)=0.001, \\
p=.977\end{array}$ & \multicolumn{2}{|c|}{$\begin{array}{l}t(353)=.950, \\
p=.321\end{array}$} \\
\hline \multicolumn{7}{|l|}{ Age } \\
\hline$<50$ & 22.1 & 77.9 & 22.7 & $24.7 \quad 75.3$ & 2.62 & 1.32 \\
\hline \multirow[t]{2}{*}{$>50$} & 31.8 & 68.2 & 42.8 & $\begin{array}{ll}30.3 & 69.7 \\
\end{array}$ & 2.27 & 1.32 \\
\hline & \multicolumn{2}{|c|}{$X^{2}(1)=3.185, p=.074$} & $(2)=9.309$, & $\begin{array}{l}X^{2} \quad(1)=1.070, \\
p=.301\end{array}$ & \multicolumn{2}{|c|}{$\begin{array}{l}t(353)=2.193 \\
p=.03\end{array}$} \\
\hline \multicolumn{7}{|l|}{ Residence } \\
\hline $\begin{array}{l}\text { Village/rural } \\
\text { area }\end{array}$ & 37.1 & 62.9 & 42.9 & 71.4 & 2.46 & 1.48 \\
\hline Town & 30.2 & 69.8 & 41.9 & 81.4 & 2.48 & 1.37 \\
\hline Small city & 28 & 72 & 38.7 & 28 & 2.48 & 1.37 \\
\hline \multirow[t]{2}{*}{ Large city } & 28.1 & 71.9 & 30.2 & 31.2 & 2.28 & 1.29 \\
\hline & \multicolumn{2}{|c|}{$X^{2}(3)=1.266, p=.737$} & $\begin{array}{l}X^{2} \\
p=.052\end{array}$ & $\begin{array}{l}X^{2}(3)=2.791, \\
p=.425\end{array}$ & $\begin{array}{l}F(3, \\
.641\end{array}$ & $\begin{aligned} & 348)= \\
= & .589\end{aligned}$ \\
\hline \multicolumn{7}{|l|}{$\begin{array}{l}\text { Marital } \\
\text { status }\end{array}$} \\
\hline Single & 26.9 & 73.1 & 34.6 & $\begin{array}{ll}42.3 & 57.7 \\
\end{array}$ & 2.20 & 1.25 \\
\hline Married & 27.9 & 72.1 & 32.6 & 24 & 2.45 & 1.34 \\
\hline Divorced & 40 & 60 & 19.4 & $\begin{array}{ll}55.6 & 44.4 \\
\end{array}$ & 1.71 & 1.01 \\
\hline Separated & 50 & 50 & 50 & 50 & 2.50 & 1.91 \\
\hline \multirow[t]{2}{*}{ Widowed } & 20 & 80 & 20 & 20 & 2.80 & 1.30 \\
\hline & \multicolumn{2}{|c|}{$X^{2}(4)=3.329, p=.504$} & $\begin{array}{l}X^{2} \quad(8)=15.386, \\
p=.052\end{array}$ & $\begin{array}{l}X^{2}(4)=19.281, \\
p=.001\end{array}$ & \multicolumn{2}{|c|}{$\begin{array}{l}F(4, \\
348)=2.650 \\
p=.033\end{array}$} \\
\hline \multicolumn{7}{|l|}{ Children } \\
\hline No Child & 39.5 & 60.5 & 47.4 & 50 & 1.97 & $\mathrm{X}$ \\
\hline 1 or more & 28 & 72 & 33.1 & 26.373 .7 & 2.41 & $\mathrm{X}$ \\
\hline $\begin{array}{l}\text { percentages. } \\
\text { Sig. } \\
\text { differences } \\
\text { in bold. }\end{array}$ & $\begin{array}{l}X^{2}(1) \\
=.143\end{array}$ & $2.147, \quad p$ & $\begin{array}{l}X^{2} \quad(2)=9.575, \quad p \\
=.008\end{array}$ & $\begin{array}{l}X^{2}(1)=9.299, \\
p=.002\end{array}$ & $\begin{array}{l}t(353 \\
p=0.8\end{array}$ & -1.880 \\
\hline
\end{tabular}


A total of 34 fields were identified in the questionnaire and participants were asked to indicate the study areas. These fields were then classified into the humanities, and the social and natural sciences. A Chi-square analysis revealed significant differences between fields for belief in God, contrasting with past research (see [89], [84], [36], [26]), however belief in after life and religious affiliation did not achieve significance.

Table 3. Belief in God and after life among fields

\begin{tabular}{|c|c|c|c|c|c|c|c|}
\hline & \multicolumn{2}{|c|}{ Belief in God ${ }^{\dagger}$} & \multicolumn{3}{|c|}{ Belief in After Life ${ }^{\dagger}$} & \multicolumn{2}{|c|}{$\begin{array}{l}\text { Religious } \\
\text { Affiliation }^{\dagger}\end{array}$} \\
\hline & None & Believer & No & Yes & $\begin{array}{l}\text { Don't } \\
\text { know }\end{array}$ & None & Affiliated \\
\hline \multicolumn{8}{|l|}{ Fields } \\
\hline Humanities & 23.8 & 76.2 & 30.2 & 53.5 & 16.3 & 23.3 & 76.7 \\
\hline Social & 17.4 & 82.6 & 24.6 & 50.7 & 24.6 & 23.2 & 76.8 \\
\hline Natural & 33.7 & 66.3 & 38.5 & 44.5 & 17.0 & 31.6 & 68.4 \\
\hline $\begin{array}{l}\bar{l}^{\dagger}=\text { percentages } \\
\text { Sig. differences } \\
\text { in bold. }\end{array}$ & \multicolumn{5}{|c|}{$\begin{array}{l}\mathrm{X}^{2}(2)=7.657, p=X^{2}(4)=5.992, p=.20 \\
.02\end{array}$} & \multicolumn{2}{|c|}{$\begin{array}{l}\mathrm{X}^{2}(2)=2.620, p= \\
.27\end{array}$} \\
\hline
\end{tabular}

In the Table 4 below, single-item questions assessed four options for possible science-religion relationship views, perceptions of the impact of science on religiosity, perceptions that scientific advances increase religious disinterest, and questions for belief in the theory of evolution and creationist explanations for the origin of life on Earth.

Table 4. Opinions on the relationship of science and religion (\%)

\begin{tabular}{lcccc}
\hline & $\begin{array}{l}\text { Strongly } \\
\text { somewhat } \\
\text { disagree }\end{array}$ & $\begin{array}{l}\text { or } \\
\text { stromewhy } \\
\text { agree }\end{array}$ & $\begin{array}{l}\text { or } \\
\text { Neither } \\
\text { agree } \\
\text { disagree }\end{array}$ \\
\hline Conflict view & 33.0 & 56.0 & 11.0 \\
\hline Independence view & 30.4 & 56.6 & 13.0 \\
\hline Collaboration view & 47.6 & 40.7 & 11.7 \\
\hline Dialogue view & 42.6 & 37.5 & 19.9 \\
\hline $\begin{array}{l}\text { Science has made me much less } \\
\text { religious }\end{array}$ & 46.7 & 36.6 & 16.7 \\
\hline $\begin{array}{l}\text { Scientific progress } \\
\text { religious disinterest }\end{array}$ & increases & 36.4 & 46.1 & 17.5 \\
\hline Belief in evolution & & 25.0 & 61.3 & 13.7 \\
\hline Belief in creationism & 58.6 & 26.5 & 14.9 \\
\hline
\end{tabular}

\section{Limitations}

First, the use of purposive sampling in the present study differs from the stratified and random sampling techniques utilized in most previous quantitative research on perceived science-religion relationships. In turn, the data is not intended to be generalizable to the population of academics across Turkey, and low sample sizes prevented analyses comparing specific disciplines with each other. Furthermore, not all university professors are "full professors" and utilizing an even broader selection criteria may yield different results. 


\section{Conclusion}

The present study investigated the religiosity of Turkish academics and their perceptions on the relationship between religion and science, and associated variables such as interpretation of the Quran, and belief in evolution and creationism. While the existing literature is replete with similar research conducted against the background of American Protestantism and sampling only elite scientists, to our knowledge this is the first study to explore this collection of variables in a Muslim majority country and with professional academics. In addition to entering unchartered research territory, the breadth of topics covered, and our use of purposive, convenience sampling underscores the exploratory nature of the findings [33], [43], that we hope will stimulate further investigations with non-Western samples.

Despite differences in cultural context and our target sample, the data presented here approximates previous research identifying academics as substantially less religious when compared to the general population. Indeed, the Turkish academics we sampled showed roughly a $20 \%$ gap when compared to non-academics on measures of belief in God, religious affiliation, perceived science-religion conflict, and belief in creationism. Causation is notoriously difficult to establish in social science. It remains unclear whether individuals who are naturally pre-disposed to the thinking styles associated with lower religiosity gravitate toward academic disciplines as a result (places where being analytical is valued and reinforced) or if academic training itself contributes to their lack of religiosity [9], [27], [60]. Contra early secularization theorists, the advancement of science and the academy have not entailed the retreat of religion among the public. Rather, scientific thinking has given us new tools to study religion and science.

\section{References}

1. Altınl1-Macić, M., and Thomas J. C. III. Spirituality and religion: an empirical study using a Turkish Muslim sample, In Z. Ağılkaya-Şahin, H. Streib, A. Ayten, and R. W. Hood (eds.), Psychology of Religion in Turkey, Leiden: Brill, 2015, pp. 160-176.

2. Asghar, A., S. Hameed, and N. K. Farahani. Evolution in biology textbooks: a comparative analysis of 5 Muslim countries, Religion \& Education 41 (1), 2014, pp. 1-15.

3. Baker, J. O., and B. G. Smith. The nones: social characteristics of the religiously unaffiliated, Social Forces 87 (3), 2009, pp. 1251-1263.

4. Baker, J. O. Public perceptions of incompatibility between "science and religion", Public Understanding of Science 21 (3), 2012, pp. 340-353.

5. Barash, D. Atheism and Darwinism, The Oxford Handbook of Atheism, Oxford: Oxford University Press, 2013.

6. Barbour, I. G. Issues in Science and Religion, London: Prentice Hall, 1966.

7. Barbour, I. G. When Science Meets Religion, SPCK, 2000.

8. Becker, L. B. Predictors of change in religious beliefs and behaviors during college, Sociological Analysis 38 (1), 1967.

9. Beit-Hallahmi, B. Explaining the secularity of academics: historical questions and psychological findings, Science, Religion and Culture 2 (3), 2015, pp. 104-119.

10. Bello, F. The young scientists, Fortune 49, 1954, pp. 142-143.

11. Bourget, D., and D.J. Chalmers. 2014. What do philosophers believe? Philosophical Studies 170 (3), 2014, pp. 465-500.

12. Boyer, P. 2008. Being human: religion: bound to believe?, Nature 455 (7216), 2008, pp. 10381039.

13. Brown, C. Religion and State: The Muslim Approach to Politics, New York: Columbia University Press, 2000.

14. Bruce, S. Secular Beats Spiritual: The Westernization of the Easternization of the West, Oxford, UK: Oxford University Press, 2017. 
15. Coleman III, T. J., C. F. Silver, and J. Holcombe. Focusing on horizontal transcendence: much more than a "non-belief", Essays in the Philosophy of Humanism 21 (2), 2013, pp. 1-18.

16. Coleman III, T. J. Review of J. David Pleins, The evolving God: Charles Darwin on the naturalness of religion, Science, Religion and Culture 2 (2), 2015, pp. 39-41.

17. Coleman III, T. J. Review of James W. Jones: Can science explain religion?- the cognitive science debate, Review of Religious Research 58 (3), 2016, pp. 459-461.

18. Cragun, R. T., B. Kosmin, A. Keysar, J. H. Hammer, and M. Nielsen. 2012. On the receiving end: discrimination toward the non-religious in the united states, Journal of Contemporary Religion 27 (1), 2012, pp. 105-127.

19. Çelik, C. Şehirleşme ve Din, Konya: Çizgi Kitanevi, 2002.

20. Dagher, Z. R., and S. BouJaoude. Science education in arab states: bright future or status quo? Studies in Science Education 47 (1), 2011, pp. 73-101.

21. Davie, G. Religion in Britain Since 1945: Believing Without Belonging, 1st ed. Oxford, UK: Blackwell, 1994.

22. Day, A. Believing in Belonging, Oxford: Oxford University Press, 2011.

23. Dennett, D. C. Darwin's Dangerous Idea: Evolution and The Meaning of Life, Penguin, 1996.

24. Diyanet İşleri Başkanlığı. Türkiye'de Dini Hayat Araştırması, Ankara: Diyanet İşleri Başkanlı̆̆ı, 2014.

25. Düzgüner, S. Maneviyat Algısı ve Yansımaları, İstanbul: Çamlıca Yayınları, 2013.

26. Ecklund, E. H., and C. P. Scheitle. Religion among academic scientists: distinctions, disciplines, and demographic, Social Problems 54 (2), 2007, pp. 289-307

27. Ecklund, E. H., and J. Z. Park. Conflict between religion and science among academic scientists? Journal for The Scientific Study of Religion 48 (2), 2009, pp. 276-292.

28. Ecklund, E. H., D. R. Johnson, C. P. Scheitle, K. R. W. Matthews, and S. W. Lewis. Religion among scientists in international context, Socius: Sociological Research for a Dynamic World 2: $237802311666435,2016$.

29. Ecklund, E. H. Science Vs. Religion, Oxford, UK: Oxford University Press, 2010.

30. European Commission. Europeans and Biotechnology in 2010. https://ec.europa.eu/research/swafs/pdf/pub_archive/europeans-biotechnology-in-2010_en.pdf.

31. Fırat, E. Üniversite Ögrrencilerinde Allah İnancı ve Benlik Saygısı İlişkisi, Doctoral dissertation, Uludağ University, 1977.

32. Freud, S. The Future of an Illusion, Civilization and its Discontents and Other Works, London, UK: The Hogarth Press: The Institute of Psycho-Analysis, 1961.

33. Funder, D. C., J. M. Levine, D. M. Mackie, C. C. Morf, C. Sansone, S. Vazire, and S. G. West. Improving the dependability of research in personality and social psychology, Personality and Social Psychology Review 18 (1), 2013, pp. 3-12.

34. Galen, L. 2017. Overlapping mental magisteria: implications of experimental psychology for a theory of religious belief as misattribution, Method \& Theory in The Study of Religion 29 (3), 2017, pp. 221-267.

35. Gould, S. Jay. Rocks of Ages: Science and Religion in the Fullness of Life, Ballantine Publishing Group, 1999.

36. Gross, N., and S. Simmons. The religiosity of American college and university professors, Sociology of Religion 70 (2), 2009, pp. 101-129.

37. Henrich, J., S. J. Heine, and A. Norenzayan. The weirdest people in the world? Behavioral and Brain Sciences 33 (2-3), 2010, pp. 61-83.

38. Hornbeck, R., and J. L. Barrett. A Christian response to Tooby and Cosmides' "evolutionary psychology: a primer", Blog. Biologos, 2014. https://biologos.org/blogs/archive/a-christianresponse-to-tooby-and-cosmides-evolutionary-psychology-a-primer.

39. Hunsberger, B. E. Apostasy: a social learning perspective, Review of Religious Research 25 (1), 1983, p. 21.

40. International Social Survey Programme. Religion Questionnaire, 2008. https://dbk.gesis.org/dbksearch/file.asp?file=ZA4950_bq.pdf. 
41. Johnson, D. C. Formal education vs. Religious belief: soliciting new evidence with multinomial logit modeling, Journal for the Scientific Study of Religion 36 (2), 1997, pp. 231.

42 .Jones, J. W. Can Science Explain Religion?: The Cognitive Science Debate, Oxford, UK: Oxford University Press, 2016.

43. Jupp, V. The SAGE Dictionary of Social Research Methods, London: SAGE, 2006

44. Kayıklık, H. Orta Yaş ve Yaşlılıkta Dinsel Eğilimler, Adana: Baki Kitabevi, 2003.

45. Keysar, A., and J. Navarro-Rivera. A world of atheism: global demographics, The Oxford Handbook of Atheism, Oxford: Oxford University Press, 2013, pp. 553-586

46. Keysar, A. Religious/non-religious demography and religion vs. Science: a global perspective, The Oxford Handbook of Secularism, Oxford: Oxford University Press, 2017.

47. Kirman, M. A. Din ve Sekülerleşme: Üniversite Gençliği Üzerinde Sosyolojik Bir Araştırma, Adana: Karahan Kitabevi, 2005.

48. Kitzmiller V. Dover Area School District. 2005. En.Wikipedia.Org. https://en.wikipedia.org/wiki/Kitzmiller_v._Dover_Area_School_District.

49. Köse, A. Popular religiosity, Psychology of Religion in Turkey. Leiden, The Netherlands: Brill, 2015.

50. Ladd, E. C., and S. M. Lipset. The Divided Academy, New York: Norton, 1975.

51. Langston, J., D. Speed, and T. J. Coleman III. Predicting age of atheism: credibility enhancing displays and religious importance, choice, and conflict in family of upbringing, Religion, Brain \& Behavior, 2018, pp. 1-19. doi:10.1080/2153599x.2018.1502678.

52. Larson, E. J., and L. Witham. Leading scientists still reject god, Nature 394 (6691), 1998, pp. 313-313.

53. Larson, E. J., and L. Witham. Scientists are still keeping the faith, Nature 386 (6624), 1997, pp. 435-436.

54. Legare, C. H., E. M. Evans, K. S. Rosengren, and P. L. Harris. The coexistence of natural and supernatural explanations across cultures and development, Child Development 83 (3), 2012, pp. 779-793.

55. Lehman, E. C. The scholarly perspective and religious commitment, Sociology of Religion 33 (4), 1972, pp. 199-216.

56. Leuba, J.H. God or Man? A Study of the Value of God to Man, London, UK: Kegan Paul, Trench, Truber \& Co, 1934.

57. Leuba, J.H. The Belief in God and Immortality: A Psychological, Anthropological and Statistical Study, Boston, MA: Sherman, French \& Company, 1916.

58. Lindholm, J. A., and H. S. Astin. Understanding the 'interior' life of faculty: how important is spirituality? Religion \& Education 33 (2), 2006, pp. 64-90.

59. Martín-Baró, I. Writings for a Liberation Psychology, Harvard: Harvard University Press, 1996.

60. McCauley, R. N. Why Religion is Natural and Science is Not, New York, USA: Oxford University Press, 2011.

61. Mercier, H., and S. Dan. The Enigma of Reason: A New Theory of Human Understanding, London, UK: Penguin Books, 2017.

62. Millî Eğitim Bakanlığı. 2017. http://mufredat.meb.gov.tr/Programlar.aspx.

63. Nesse, R. M., and S. C. Stearns. The great opportunity: evolutionary applications to medicine and public health, Evolutionary Applications 1 (1), 2008, pp. 28-48.

64. Oprisko, R. Superpowers: the American academic elite, Georgetown Public Policy Review, 2012. http://gppreview.com/2012/12/03/superpowers-the-american-academic-elite/.

65. Pew Research Center. In America, Does More Education Equal Less Religion? 2018. http://assets.pewresearch.org/wp-content/uploads/sites/11/2017/04/25115302/Religion-and-

education-FULL-REPORT.pdf. 
66. Pew Research Center. Public Opinion on Religion and Science in The United States, 2009. http://www.pewforum.org/2009/11/05/public-opinion-on-religion-and-science-in-the-unitedstates/.

67. Pew Research Center. The Global Religious Landscape, 2012.

68. Pew Research Center. The World's Muslims: Religion, Politics and Society, 2013. http://assets.pewresearch.org/wp-content/uploads/sites/11/2013/04/worlds-muslims-religionpolitics-society-full-report.pdf.

69. Pew Research Center. Religion in America: U.S. religious data, demographics and statistics, Pew Research Center's Religion \& Public Life Project, 2014. http://www.pewforum.org/religiouslandscape-study/educational-distribution/.

70. Preston, J. L., and F. Shin. Spiritual experiences evoke awe through the small self in both religious and non-religious individuals, Journal of Experimental Social Psychology 70, 2017, pp. 212-221.

71. Provine, W. B. Evolution, religion, and science, The Oxford Handbook of Religion and Science, Oxford, UK: Oxford University Press, 2006, pp. 667-680.

72. Quillen, E. G. Discourse analysis and the definition of atheism, Science, Religion and Culture 2 (3), 2015, pp. 25-35.

73. Ragan, C., H. N. Malony, and B. Beit-Hallahmi. Psychologists and religion: professional factors and personal belief, Review of Religious Research 21 (2), 1980, pp. 208-217.

74. Roe, A. The Making of a Scientist, New York: Dodd, Mead, 1952.

75. Roizen, J., O. Fulton, and M. A. Trow. Technical report: 1975 Carnegie council national surveys of higher education, Berkeley: Center for Studies in Higher Education, University of California, 1978.

76. Rothman, S., S. R. Lichter, and N. Nevitte. Politics and professional advancement among college faculty, The Forum 3 (1), 2005.

77. Schleifer, C., S. G Brauer, and V. R Patel. Patterns of conservative religious belief and religious practice across college majors, Sociology of Religion 79 (3), 2018, pp. 299-322.

78. Schwadel, P. Does higher education cause religious decline?: a longitudinal analysis of the within- and between-person effects of higher education on religiosity, The Sociological Quarterly 57 (4), 2016, pp. 759-786.

79. Sevinç, K., and Z. Ağılkaya-Şahin. Past and present of psychology of religion in turkey, In Z. Ağılkaya-Şahin, H. Streib, A. Ayten, and R. W. Hood (eds.), Psychology of Religion in Turkey, Leiden: Brill, 2015, pp. 3-30.

80. Sevinç, K., R. W. Hood Jr., and T. J. Coleman III. Secularism in Turkey, The Oxford Handbook of Secularism, P. Zuckerman and J.R. Shook (eds.), Oxford, UK: Oxford University Press, 2017, pp. 155-171.

81. Sevinç, K., T. J. Coleman III, and R. W. Hood Jr. Non-belief: an Islamic perspective, Secularism and Nonreligion 7, 2018.

82. Sevinç, K. İnançsızlık Psikolojisi, İstanbul: Çamlıca Yayınları, 2017.

83. Shook, J.R. The God Debates, Malden, MA: Wiley-Blackwell, 2010.

84. Stark, R., L. R. Iannaccone, and R. Finke. Religion, science, and rationality, The American Economic Review 86 (2), 1996, pp. 433-437.

85. Stark, R. Secularization, R.I.P., Sociology of Religion 60 (3), 1999, p. 249.

86. Streib, H., and R. W Hood Jr. Semantics and Psychology of Spirituality, Springer, 2016.

87. Stubager, R. Education effects on authoritarian-libertarian values: a question of socialization, The British Journal of Sociology 59 (2), 2016, pp. 327-350.

88. Taplamacıoğlu, M. Yaşlara göre dini hayatın şiddet ve kesafeti üzerine bir anket denemesi, Ankara Üniversitesi İlahiyat Fakültesi Dergisi 10, 1962, pp. 141-151.

89. Vaughan, T. R., D. H. Smith, and G. Sjoberg. The religious orientations of american natural scientists, Social Forces 44 (4), 1966, p. 519-526. 
90. Warner, J., and A. Clauset. The academy's dirty secret, Slate Magazine, 2015. http://www.slate.com/articles/life/education/2015/02/university_hiring_if_you_didn_t_get_your_p h_d_at_an_elite_university_good.html.

91. Weber, M. The Protestant Ethic and the Spirit of Capitalism, London, UK: Routledge, 1930.

92. Winseman, A. L. Does more educated really $=$ less religious?, 2003. https://news.gallup.com/poll/7729/does-more-educated-really-less-religious.aspx.

93. Yapıcı, A. Geleneksellik ile modernlik arasına sıkışan din anlayışları ve dindarlık, DEM Dergi 1 (2), 2007, pp. 24-29.

\section{Notes}

1. Throughout this paper we use the terms nonbelief and atheism interchangeably to refer to the lack of belief in gods. Nonreligion and nonreligiosity is a broader category indicating a degree of distance from religion that encompasses the previous terms, but does not necessarily imply atheism (for discussion, see [81]).

2. Disaffiliation did not reach statistical significance.

3. Lest we need to convince anyone of the absolute value of evolutionary thinking, the single example of its priceless and enduring contribution to medicine and public health should suffice (cf. [63]). 